\title{
Evidence of large Anacardiaceae trees from the Oligocene-early Miocene Santiago Formation, Azuero, Panama
}

\section{Evidencia de árboles grandes de Anacardiaceae del Oligoceno-Mioceno temprano en la Formación Santiago, Azuero, Panamá}

Oris Rodríguez-Reyes ${ }^{1,2, *}$, Emilio Estrada-Ruiz ${ }^{3}$, Peter Gasson ${ }^{4}$

${ }^{1}$ Facultad de Ciencias Naturales, Exactas y Tecnología, Departamento de Botánica, Universidad de Panamá. Apartado 00017, 0824, Panama.

${ }^{2}$ Smithsonian Tropical Research Institute, Box 0843-03092, Balboa, Ancón Republic of Panama, Panama.

${ }^{3}$ Departamento de Zoología, Laboratorio de Ecología, Escuela Nacional de Ciencias Biológicas, Instituto Politécnico Nacional, Prolongación de Carpio y Plan de Ayala s/n, 11340, GDMX, Mexico.

${ }^{4}$ Royal Botanic Gardens, Kew, Richmond, Surrey TW93AB, United Kingdom.

*Corresponding author: (O. Rodrguez-Reyes) orisrodriguez@gmail.com

\section{How to cite this article:}

Rodríguez-Reyes, O., Estrada-Ruiz, E., Gasson, P., 2020, Evidence of large Anacardiaceae trees from the Oligoceneearly Miocene Santiago Formation, Azuero, Panama: Boletín de la Sociedad Geológica Mexicana 72(2), A300719. http://dx.doi. org/10.18268/BSGM2020v72n2a300719

Manuscript received: April 26, 2019

Corrected manuscript received: July 20, 2019

Manuscript accepted: July 30, 2019

Peer Reviewing under the responsibility of Universidad Nacional Autónoma de México.

\section{ABSTRACT}

We have poor knowledge of the plants that inhabited Central America during the Cenozoic. One of the families with a rich fossil record worldwide, especially for the Oligocene and Miocene epochs is Anacardiaceae. Llanodelacruzoxylon sandovalii gen. et sp. nov. is the first formal record of a fossil wood of Anacardiaceae found in Panama and Central America to date. We collected the fossil woods in the Oligocene-Miocene Santiago Formation, in the Azuero Peninsula, Panama. Among the samples collected we have described and identified this new fossil genus of Anacardiaceae, using wood anatomical characters and extensive comparisons with fossil and extant material. These two specimens share diagnostic features with several Anacardiaceae woods, such as: large vessels $(>200 \mu \mathrm{m})$, simple vessel-ray pitting and rays mostly uniseriate with large crystals. The occurrence of these Anacardiaceae in Panama by the Oligocene to Miocene adds to the understanding of the historical biogeography of the family and supports Central America (including Mexico) being a divergence center of the Anacardiaceae.

Keywords: Anacarcadiaceae, Oligocene-Miocene, fossil wood, Santiago Formation, Panama.

\section{RESUMEN}

Tenemos poco conocimiento de las floras que habitaron América Central durante el Cenozoico. Anacardiaceae es una de las familias con un abundante registro fósil a nivel mundial, especialmente para el Oligoceno y Mioceno. Llanodelacruzoxylon sandovalii gen. et sp. nov. es el primer registro de una madera fósil de Anacardiaceae encontrada en Panamá y América Central hasta ahora. Recolectamos las maderas fósiles en la Formación Santiago, Península de Azuero, Panamá. Describimos e identificamos estos especímenes como Anacardiaceae, usando caracteres anatómicos de la madera y extensas comparaciones de material fósil y moderno. Estos dos especimenes comparten características diagnósticas con maderas de Anacardiaceae, como son: vasos grandes (>200 $\mu \mathrm{m})$, punteaduras vaso-radiales simples y radios uniseriados con cristales grandes. La presencia de Anacardiaceae en Panamá para el Oligoceno-Mioceno, ayuda a entender la historia biogeográfica de la familia y soporta la idea de América Central (incluyendo México) como un centro de divergencia de Anacardiaceae.

Palabras clave: Anacarcadiaceae, Oligoceno-Mioceno, Madera fósil, Formación Santiago, Panamá. 


\section{Introduction}

Anacardiaceae and Burseraceae (Sapindales) provide an excellent opportunity for investigating the biogeographic history of tropical diversification and the relative importance of movement and climatic adaptation in angiosperm evolution (Weeks et al., 2014). These families occur on every continent except Oceania and Antarctica and are major elements of temperate, seasonally dry tropical forests and tropical wet forests (Gentry, 1988; Pennington et al., 2010). Although these two families have approximately the same number of species, the Anacardiaceae occupy a wider range of habitats (Weeks et al., 2014).

Anacardiaceae/Burseraceae have a long evolutionary history. Xie et al. (2014) suggested the divergence occurred approximately $73 \mathrm{Ma}$, based on the oldest fossil record of Anacardiaceae (Estrada-Ruiz et al., 2010). The fossil record of Anacardiaceae is extensive worldwide (Stevens, 2001 onwards), with approximately 80 specimens associated with the family (e.g., Kruse, 1954; Wheeler and Manchester, 2002; MartínezCabrera and Cevallos-Ferriz, 2004; Gregory et al., 2009; Estrada-Ruiz et al., 2010; Pérez-Lara et al., 2017; Woodcock et al., 2017). The majority of these records are from South America and Asia (Weeks et al., 2014).

There are only two reports of fossil Anacardiaceae from Panama, both discovered in the Azuero Peninsula: Dracontomelon L. endocarps from the Eocene Tonosí Formation (Herrera et al., 2012) and one fossil wood that resembles Anacardiaceae/Burseraceae from the Oligocene-Miocene Santiago Formation, found in the surrounds of the Ocú town (Jud and Dunham, 2017).

Here we report the largest fossil trunk discovered in Panama and probably, Central America, to date. The wood has several features that support an affinity to the Anacardiaceae, although they are not found in any specific extant genus. Consequently, we erect a new fossil-genus and species of Anacardiaceae.
This new record is presented as additional evidence that Central America (including Mexico) was a divergence center of the Anacardiaceae.

\section{Materials and methods}

The two specimens reported herein were collected in the Veraguas province in Panama. STRI $44038 \mathrm{~B}$ is a large trunk collected on a private farm in Llano de La Cruz (latitude 08 09' 4.7” N; longitude $80^{\circ} 53^{\prime} 11.2^{\prime \prime} \mathrm{W}$ ) (Figure 1).

The preserved holotype fossil trunk is $\sim 20 \mathrm{~m}$ in length and $80 \mathrm{~cm}$ in preserved diameter (Figure $2 \mathrm{~A}$ to $2 \mathrm{C}$ ). The paratype STRI 45789, was collected in Boquerones, San Francisco (latitude $08^{\circ} 13^{\prime} 46.4$ " N; longitude $80^{\circ} 51^{\prime}$ '45.1" W). The paratype has a size of approximately $9.3 \mathrm{~cm}$ in wide and $8.5 \mathrm{~cm}$ in length.
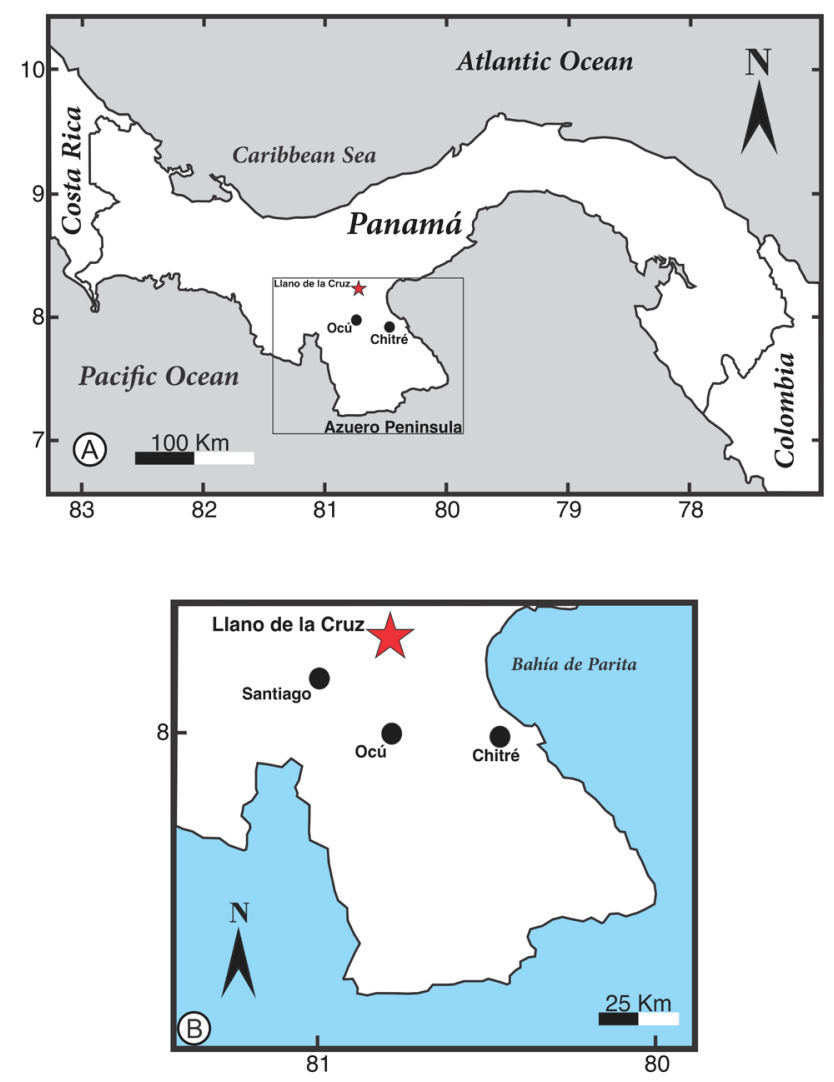

Figure 1 A) Map of Panama and the Azuero Peninsula, and B) It shows the Holotype collection locality 

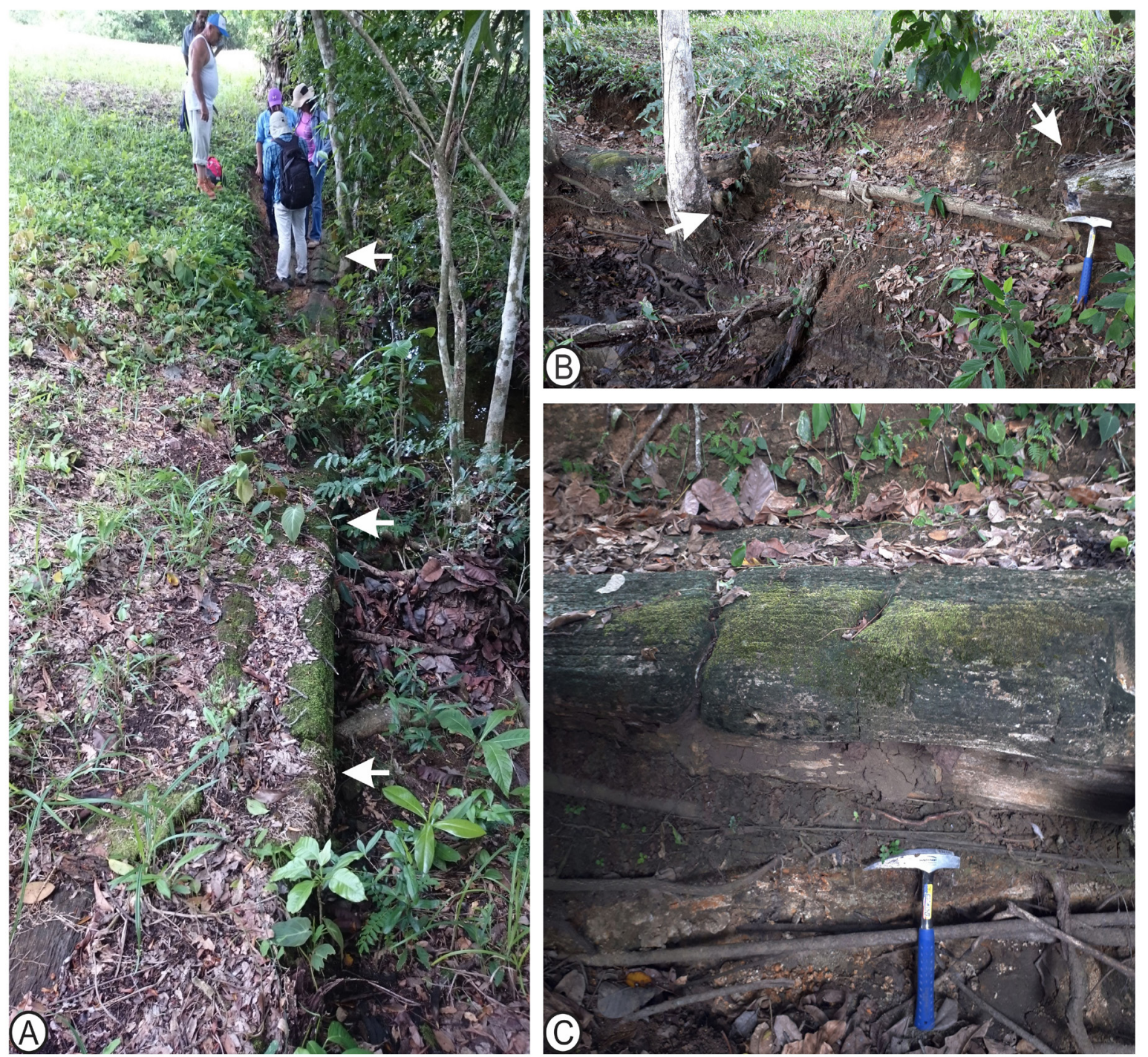

Figure 2 The "big tree" and its original position in the field. A, Preserved length of the "big tree" (arrows). B, Logs split from the original preserved total tree length. Follow arrows to see continuity of the fossil extent. C, Preservation of the external part of the fossil wood.

\subsection{GEOLOGICAL CONTEXT}

STRI 44038 is the largest fossilized trunk found in Panama to date. The trunk is lying within layers of sandy mudrock and sedimentary breccia, parallel to bedding. Fining upward sequences indicate fluvial environments as the main depositional system. STRI 45789, as all the others fossil woods we have collected from this area, is found as a float specimen on cattle farms covered with vegetation, as the most resistant 'clasts' from differential weathering. This area has been mapped as part of the Oligocene to Miocene Santiago Formation, sometimes referred to as Macaracas Formation that outcrops in the Macaracas Basin (Buchs et al., 2011). Kolarsky et al. (1995) reported samples of pollen, foraminifera, and nannofossils from the Macaracas Basin in central Azuero and concluded that they support a late Oligocene to early Miocene age, although the preservation of the specimens was poor.

The age of the Santiago Formation has not been clearly determined due to its stratigraphic complexity, lack of good outcrops, and absence 
of radiometric elements for dating. We are currently testing detrital zircons and studying the biostratigraphy.

\subsection{AGGESSION DATA, SPEGIMEN PREPARATION, AND IMAGING}

Petrographic thin sections of fossil material were prepared in transverse (TS), radial longitudinal (RLS) and tangential longitudinal (TLS) sections. Sections were mounted on glass slides using EpoFix resin, ground to a thickness of $\sim 30 \mu \mathrm{m}$, and coverslips were affixed with Canada balsam. Material was observed and imaged using an Olympus BX53 and digital camera SC100 with sensor CMOS of 10.5 Mpix and a Zeiss AXIO Zoom V16, photographed with an AxioCam MRc5 camera.

The fossil woods were compared with the available images of modern and fossil woods in the Inside Wood Database (IWD; insidewood.lib.ncsu. edu; Wheeler, 2011) and literature (e.g., Terrazas, 1994, 1999; León, 2003, 2014; Woodcock et al., 2017).

\subsection{IAWA FEATURE DESGRIPTION AND GODING}

We described the fossil wood specimens following the International Association of Wood Anatomists (IAWA) List of Features for Hardwood Identification (IAWA Committee, 1989). For quantitative data of vessel frequency, ray density, and vessel grouping, we made measurements in 10 different fields of $1 \mathrm{~mm} 2$ of area. For other quantitative features, we obtained a minimum of 25 measurements (mean vessel diameter, intervessel pit diameter, vessel-ray parenchyma pit diameter, vessel element length, and ray height). In the descriptions, we give a list of the IAWA character code numbers. We use the symbol '?' to indicate that there is uncertainty as to whether the feature is present or absent and " $\mathrm{v}$ " to indicate that the feature is variable in occurrence.

\section{Results}

\subsection{SYSTEMATIC PALEOBOTANY}

Order - Sapindales Dumortier

Family - Anacardiaceae Lindley

Genus - Llanodelacruzoxylon Rodríguez-Reyes, Estrada-Ruiz et Gasson, gen. nov.

Species - Llanodelacruzoxylon sandovalii Rodríguez-Reyes, Estrada-Ruiz et Gasson, sp. nov. (Figures 2 to 4$)$.

Diagnosis: Growth rings are indistinct; wood is diffuse porous; vessels are solitary combined with a few short radial multiples; perforation plates simple; intervessel pitting alternate; polygonal and medium to large; vessel-ray parenchyma pits mainly circular with reduced borders, axial parenchyma apotracheal diffuse, scanty paratracheal to vasicentric, and slightly aliform, rays heterocellular, mostly uniseriate and very rarely biseriate, non septate fibers, thin to thick walled, large solitary rhomboidal crystals very abundant in body and upright ray cells.

Species diagnosis: As for the genus

Etymology: The generic name refers to the Llano de la Cruz locality, where the holotype was collected. The specific epithet is in recognition of Mr. Carlos Sandoval, who provided samples of the large trunk for this study.

Holotype: STRI 44038 B

Paratype: STRI 45789

Repository: Center for Tropical Paleoecology and Archaeology, Smithsonian Tropical Research Institute, Panama City, Panama.

Type locality: Llano de la Cruz, Veraguas (Azuero Peninsula).

Latitude $08^{\circ} 09^{\prime} 4.7^{\prime \prime} \mathrm{N}$ and longitude $80^{\circ}$ 53' $11.2 " \mathrm{~W}$.

Description in IAWA feature numbers: 2p, 5p, 10a $11 \mathrm{a}, 13 \mathrm{p}, 22 \mathrm{p}, 31 \mathrm{p}, 40 \mathrm{a}, 41 \mathrm{a}, 66 \mathrm{p}, 78 \mathrm{p}, 79 \mathrm{p}, 98 \mathrm{a}$, 99a, 100a, 130a, 136p, 189p.

Description: Description based on two samples. 

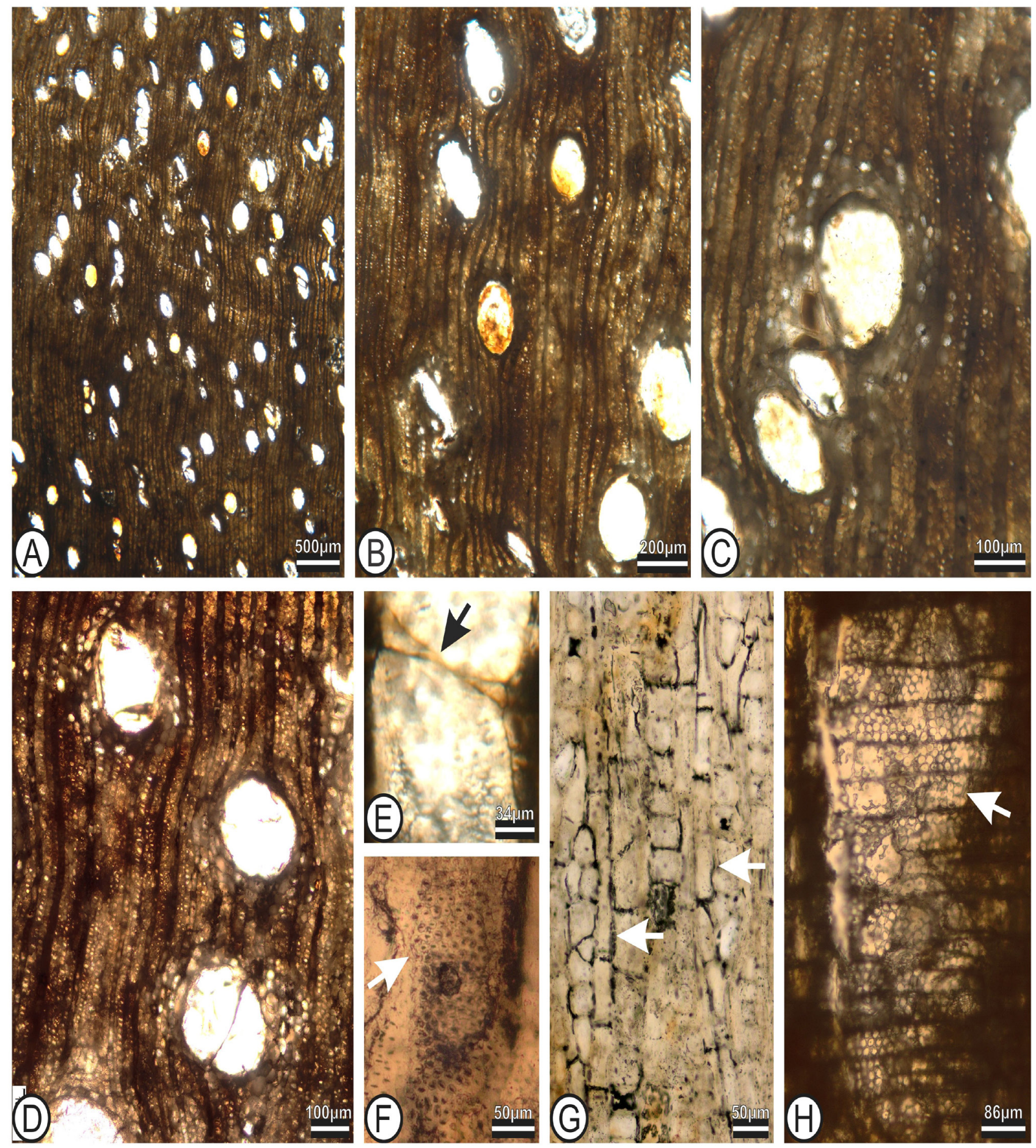

Figure 3 Llanodelacruzoxylon sandovalii Rodríguez-Reyes, Estrada-Ruiz et Gasson gen. et sp. nov. A-F, STRI 44038B; G-H, STRI 45789. A, Transverse section (TS). Diffuse porous wood with vessels solitary and few in radial multiples. B, (TS). Solitary vessels and diffuse axial parenchyma. C, (TS). Three vessels with vasicentric parenchyma. D, (TS). Close up of vessel with vasicentric parenchyma. E, Tangential longitudinal section (TLS). Simple perforation plate (arrow). F, (TLS). Alternate intervessel pits (arrow). G, (TLS). Showing parenchyma strands (arrows). H, Radial Longitudinal Section (RLS). Detail of the vessel-ray parenchyma pits with reduced borders, round in shape (arrow). 

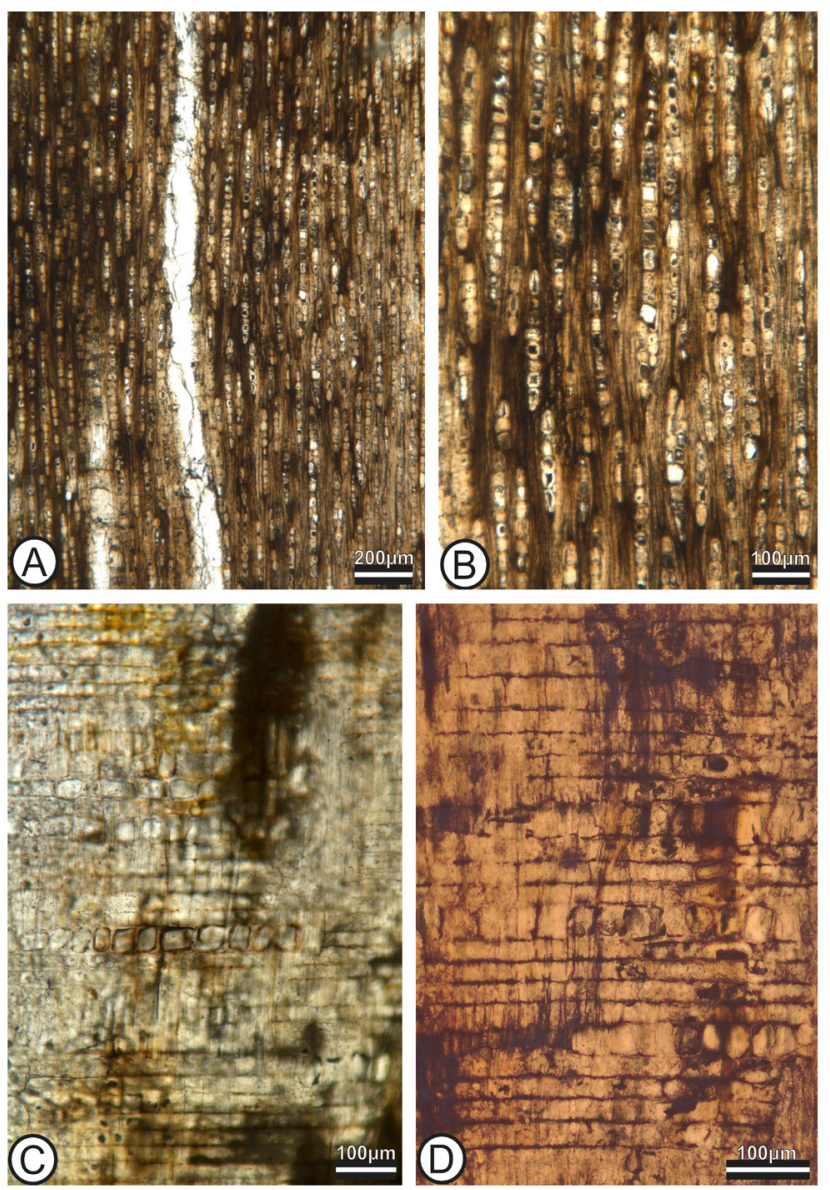

Figure 4 Llanodelacruzoxylon sandovalii Rodríguez-Reyes, Estrada-Ruiz et Gasson gen. et sp. nov. Holotype STRI 44038B. A, (TLS). Rays mostly uniseriate, some biseriate. B, (TLS). Uniseriate rays with crystals. C, (RLS). Heterocellular rays, procumbent and square body cells in radial alignment. D, (RLS). Crystals in the square body cells.

Growth rings indistinct to absent. Wood is diffuse porous; vessels are solitary $(66 \%)$ combined with a few short radial multiples $(34 \%)$ of $2-3(-5)$ (Figures 3A to 3D), circular to oval in outline (Figure 3D); vessel mean tangential diameter 154 $($ range $=96-205, \mathrm{SD}=35.8) \mu \mathrm{m}($ Figure $3 \mathrm{D}) ; 6$ (range $=4-9, \mathrm{SD}=1.5$ ) vessels per square millimeter; perforation plates are simple (Figue 3E); intervessel pits are alternate and crowded, polygonal and medium to large (mean pit diameters 8 - $12 \mu \mathrm{m}$ ) (Figure 3F); vessel-ray parenchyma pits with reduced borders, round in shape (mean pit diameters $7.5-12 \mu \mathrm{m}$ ) (Figure $3 \mathrm{H}$ ); mean vessel element length is 365 (range $=203-504, \mathrm{SD}=$
87) $\mu \mathrm{m}$. Axial parenchyma is apotracheal diffuse and scanty paratracheal to vasicentric (Figures 3B to 3D). Some vessels possess slightly aliform parenchyma (Figure 3G). Parenchyma strands are 6-celled (Figure 3G).

Rays heterocellular, mostly uniseriate, very rarely biseriate (Figure $4 \mathrm{~A}$ and $4 \mathrm{~B}$ ). Mean ray frequency is 19 per $\mathrm{mm}$ (range $=15-23, \mathrm{SD}=2.7$ ) (Figure 4A and 4B), composed of mixed (procumbent and upright) cells throughout the ray body (Figure 4C and 4D). Non-septate fibers (Figure 4B), thin to thick walled. Solitary, non-chambered, rhomboidal crystals very abundant in body and upright ray cells in radial alignment in procumbent ray cells (Figure 4G). The crystals are large, 43 to $50 \mu \mathrm{m}$ in length and 22 to $39 \mu \mathrm{m}$ in width (Figures 4C to 4D).

\section{Discussion}

\subsection{INSIDE WOOD SEARGH}

Burseraceae and Anacardiaceae are anatomically very similar, however Anacardiaceae can be distinguished by having more abundant axial parenchyma, more frequent septate fibers, and fewer occurrences of radial canals (Terrazas, 1994; Bell et al., 2010).

The most restrictive search we obtained in the IWD included the following characters: growth rings indistinct or absent (2p); wood diffuse porous (5p); vessels in radial multiples of 4 or more common absent (10a); vessel clusters common absent (11a); perforation plates simple (13p); intervessel pits alternate (22p); vessel-ray pits with much reduced borders (31p); vessel mean tangential diameter $<50 \mu \mathrm{m}$ absent (40a); vessel mean tangential diameter $50-100 \mu \mathrm{m}$ absent (41a); fibers non-septate (66p); axial paratracheal parenchyma scanty (78p), Axial paratracheal parenchyma vasicentric (79p); rays 4-10 cells wide absent (98a); rays $>10$-seriate absent (99a); Rays with multiseriate portion(s) as wide as uniseriate portions absent (100a); radial canals absent (130a); prismatic 
crystals present (136p); tree (189p). This combination of traits led to 18 results that included mostly species of Anacardiaceae and Myrtaceae. Myrtaceae can be ruled out because of exclusively solitary vessels, greater abundance of parenchyma compared to this fossil wood and vessel ray pitting with distinct borders. The other results consisted of only one or two species in families such as: Erythroxylaceae, Gentianaceae, Juglandaceae, Malvaceae, Moringaceae, Oxalidaceae, Phyllanthaceae and Rhamnaceae. Abundance of banded apotracheal parenchyma rules out the Erythroxylaceae and Malvaceae. The single result of Rhamnaceae is ruled out by its occasional distinct growth ring boundaries, vessel grouping common and more abundant parenchyma. Storied rays distinguish Moringaceae. Sarcotheca glauca (Oxalidaceae) possesses intervessel pitting large $(>10 \mu \mathrm{m})$ and are mainly shrubs, and not trees as the fossil. different from the fossil. Bridelia micrantha (Phyllanthaceae) has several features distinct from the fossil, occasional reticulate perforation plates, vessels in diagonal pattern and vessel grouping common, vessel-ray pits of different sizes in the same ray cell and septate fibres present.

After the comparison we conducted, Anacardiaceae is the family that most resembles the fossil studied herein. We detail the genus identification further in the discussion.

\subsection{GOMPARISON WITH ANAGARDIAGEAE GENERA}

The mosaic of traits described from these two specimens, growth rings indistinct, wood diffuse porous, vessels solitary combined with very few short radial multiples, perforation plates simple, intervessel pitting alternate, vessel-ray parenchyma pits mainly circular with reduced borders, axial parenchyma apotracheal diffuse and scanty paratracheal to vasicentric, rays heterocellular, mostly uniseriate, very rarely biseriate rays, non septate fibers and abundance of large solitary rhomboidal crystals in procumbent and upright ray cells lead to the Anacardiaceae.

The most restrictive search in IWD included the following Anacardiaceae taxa: Faguetia falcata,
Mangifera caesia, Mangifera cf. griffithii and Protorhus sp. Faguetia falcata has vessel-ray pitting in palisade and gash like, tyloses common and occasional bands of parenchyma. All these characters are absent in the fossils. The most noticeable differences between the Mangifera species from the results and $L I$. sandovalii, are based on wider rays and bands of parenchyma and occasionally it has a low ray density $(<4$ per linear $\mathrm{mm})$. Protorhus possesses scalariform perforation plates and septate and non- septate fibers, whereas the fossil has simple perforation plates and non-septate fibers.

At tribe level, this fossil shares several characters with the Anacardieae (sensu Engler), such as growth rings indistinct, wood diffuse porous, vessels with no arrangement, intervascular pitting polygonal and large $(>10 \mu \mathrm{m})$, mean vessel density $(<5$ per mm2), non septate fibres, paratracheal parenchyma present, but no abundant; rays uniseriate to biseriate and rays heterocellular. We stress on the intervessel pitting size that is larger in the Anacardieae compared to the other tribes (Terrazas, 1994)

From the results in Inside Wood, we note that none of the taxa match the fossil. We then consulted the largest Anacardiaceae micromorphology slide collection from Instituto de Biología, Universidad Nacional Autónoma de México, under supervision of Dra. Teresa Terrazas. From that revision it was revealed that although all characters in this fossil occur in Anacardiaceae, no modern genus possesses the diagnostic features. Moreover, the pattern of vessel-ray pitting in the fossil is not common in modern Anacardiaceae. Although vessel-ray pits are all simple, circular and small $(7.6$ to $12.0 \mu \mathrm{m})$, most anacards have larger pits in palisade and gash-like pattern. We mention Mangifera as one of the genera that has a similar pattern of vessel-ray pits. Mangifera also has a good number of species with uniseriate rays and abundant crystals in procumbent and upright ray cells (Dra. Teresa Terrazas com. pers.). There are some genera that have pits smaller than $8 \mu \mathrm{m}$, for example Cotinus, Dobinea, Haplorhus, Lithraea, Rhus, Schinus, Toxicodendron, and Trichoscypha. These 
Table 1. Summary of comparison between Anacardiaceae fossil woods and Llanodelacruzoxylon sandovalii. Data were obtained from the Inside Wood Database (Wheeler et al., 2011).

\begin{tabular}{|c|c|c|c|}
\hline Taxon & Distinct characteristics & Age & References \\
\hline Anacardioxylon & Septate fibres, rays 4-10 seriate, radial canals & Cretaceous-Miocene & Inside Wood, 2019 \\
\hline Anacardium & Septate fibres, vascular/vasicentric tracheids & Eocene & Woodcock et al., 2017 \\
\hline Astroniumxylon & Radial canals, septate fibres & Pliocene & $\begin{array}{l}\text { Franco and Brea, 2008; Franco } \\
2009\end{array}$ \\
\hline Bosquesoxylon & Septate fibres, rays $4-10$ seriate & Eocene & Pérez-Lara et al., 2017 \\
\hline Bouea & Banded parenchyma, vessels $50-100 \mu \mathrm{m}$ & Miocene & Agarwal, 1988 \\
\hline Buchanioxylon & Septate fibres, radial canals & Miocene & Roy and Ghosh, 1979-80 \\
\hline cf Mangifera & Aliform parenchyma, marginal parenchyma & Eocene & Woodcock et al., 2017 \\
\hline Dracontomeloxylon & Septate fibres, rays $4-10$ seriate & Cretaceous- Miocene & Inside Wood, 2019 \\
\hline Dracontomelumoxylon & Tyloses common, septate fibres, rays 4-10 seriate & Cretaceous & Inside Wood, 2019 \\
\hline Edenoxylon & Wood semi-ring porous, radial canals & Paleocene-Eocene & Allen, 2017 \\
\hline Glutoxylon & Banded parenchyma, radial canals & Miocene-Pliocene & Inside Wood, 2019 \\
\hline Holigarnoxylon & Tyloses common, aliform parenchyma & Eocene-? Miocene & Inside Wood, 2019 \\
\hline Lanneoxylon & Septate fibres, rays $4-10$ seriate, radial canals & Miocene & Inside Wood, 2019 \\
\hline Loxopterygium & Tyloses common, septate fibres, radial canals & Oligocene & Méndez-Cárdenas et al., 2014 \\
\hline Mangiferoxylon & $\begin{array}{l}\text { Growth rings distinct, aliform parenchyma, banded } \\
\text { parenchyma }\end{array}$ & Miocene-Pliocene & Inside Wood, 2019 \\
\hline Maureroxylon & Growth rings distinct, septate fibres & Eocene & Wheeler and Manchester, 2002 \\
\hline Melanorrhoeoxylon & $\begin{array}{l}\text { Tyloses common, banded parenchyma, homocellular } \\
\text { rays, radial canals }\end{array}$ & Miocene & Inside Wood, 2019 \\
\hline Pistacioxylon & $\begin{array}{l}\text { Growth rings distinct, Vessels in diagonal pattern, } \\
\text { helical thickenings, tyloses common, radial canals }\end{array}$ & Miocene & Cheng et al., 2012 \\
\hline Post Oregon site & $\begin{array}{l}\text { Growth rings distinct, wood ring-porous, vessels in } \\
\text { tangential bands }\end{array}$ & Eocene & Inside Wood, 2019 \\
\hline Resinaxylon & Vessels in diagonal pattern, septate fibres, radial canals & Oligocene & Pujana, 2009 \\
\hline Rhus & $\begin{array}{l}\text { Wood semi-ring porous, vessel clusters common, } \\
\text { septate fibres, }\end{array}$ & Eocene-Oligocene & Inside Wood, 2019 \\
\hline Schinosipxylon & $\begin{array}{l}\text { Tyloses common, rays } 4-10 \text { seriate, septate fibres, } \\
\text { radial canals }\end{array}$ & Pliocene & Inside Wood, 2019 \\
\hline Sclerocaryoxylon & Septate fibres, axial parenchyma absent, radial canals & Miocene & Biondi, 1981 \\
\hline Swintonioxylon & Tyloses common, banded parenchyma, radial canals & Miocene-Pliocene & Inside Wood, 2019 \\
\hline Tapirira & Tyloses common, septate fibres, radial canals & Eocene & Inside Wood, 2019 \\
\hline Comparative & fossil genera of Burseraceae & Eocene & Wheeler and Manchester, 2002 \\
\hline Boswellioxylon indicum & $\begin{array}{l}\text { Vessel-ray pitting similar to intervessel pits, radial } \\
\text { canals }\end{array}$ & Cretaceous & Dayal, 1965 \\
\hline $\begin{array}{l}\text { Burseroxylon } \\
06010441703\end{array}$ & Septate fibres, rays 4-to-10 seriate & Miocene to Pliocene & Inside Wood, 2019 \\
\hline Canarioxylon & Septate fibres, tyloses common & Miocene to Pliocene & Inside Wood, 2019 \\
\hline Canarium & Radial canals, septate fibers, ays 4-to-10 seriate & Miocene to Pliocene & Awasthi and Srivasta, 1990 \\
\hline Sumatroxylon & Septate fibers, radial canals, growth rings distinct & Miocene & Den Berger, 1923 \\
\hline Tetragastroxylon & Tyloses common, septate fibers radial canals & Miocene & Martinez-Cabrera et al., 2006 \\
\hline
\end{tabular}


genera do not have aliform parenchyma. Trichoscypha has unilateral winged-aliform, but it presents few uniseriate rays as well as radial canals.

\subsection{COMPARISON WITH OTHER FOSSIL WOODS OF ANAGARDIACEAE}

There are abundant records of anacardiaceous fossil woods. More than eighty wood types have been reported worldwide (Franco and Brea, 2008; Franco, 2009; Pujana, 2009; Gregory et al., 2009; Cheng et al., 2012; Mendez-Cardenas et al., 2014; Shukla and Mehrotra, 2016; Allen, 2017; PerezLara et al., 2017; Wheeler et al., 2017; Woodcock et al., 2017). A good number of the records come from Europe, Asia and South America (Ramírez et al., 2000).

We surveyed the Anacardiaceous fossil woods using the IWD, in order to elucidate whether $L I$. sandovalii resembles other previously reported fossil taxa. We summarize this survey in Table 1. We did not find any fossil wood that has all the characters in these specimens.

We remark that the vessel-ray pitting pattern in our fossil wood is the same as observed in Anacardium incahuasi from early Eocene of the Fossil Forest Piedra Chamana in Peru (Woodcock et al., 2017). However, A. incahuasi differs from our wood in having septate fibers, vascular vasicentric tracheids, rays $1-3$ cells wide. Therefore, we erect a new fossil anacard genus and species.

\subsection{PALEOEGOLOGICAL AND BIOGEOGRAPHICAL REMARKS}

STRI 44038B preserved trunk is $\sim 20 \mathrm{~m}$ in length and $2.5 \mathrm{~m}$ wide. The dimensions suggest this "big tree" was probably $\sim 35 \mathrm{~m}$ high (Figures 2A to 2C), according to Niklas' (1995) equation. We confirmed the sandstones where it was lying were described as part of the Santiago Formation because of their properties and geological observations in the field.

Anacardiaceae and Burseraceae are good families to understand migration patterns of angiosperm families (Angiosperm Phylogeny Group,2016). Both families probably originated in Asia and diverged during the Cretaceous (Xie et al., 2014). Long distance dispersal played a key role in migration to North and South America (Weeks et al., 2014; Xie et al., 2014). Anacardiaceae displays a much wider diversity of fruit morphology and tolerance to a more diverse range of habitats than Burseraceae. This difference may help explain why Anacardiaceae has become more widespread and has successfully occupied a wider range of biomes than Burseraceae (Weeks et al., 2014).

Weeks et al. (2014) performed ancestral area reconstructions highly congruent with the fossil record. Anacardiaceae diversified during the Cretaceous and expanded into sub-Saharan Africa. From there, the route to conquer South America probably took place during the Paleogene. It is suggested that Anacardiaceae continued to steadily colonize Eurasia and temperate zones during the Miocene, when it had a widespread geographic range and likely a diversity of climatic tolerances (Weeks et al., 2014). The fossil record of Anacardiaceae was augmented especially during the Oligocene in Central America. Reports of Anacardiaceae decrease towards the Miocene.

Herrera et al. (2012) found endocarp rich assemblages in the Eocene Tonosí Formation (Azuero, Panama) that suggested a diverse rainforest. From this Formation, they identified only one Anacardiaceae (Dracontomelon) from permineralized endocarps, that is a genus only inhabiting Asia and Africa today. Based on the absence of this Anacardiaceae genus in fossil beds from the lower Miocene Cucaracha Formation, they conclude this could represent an example of local extinctions and that long time dispersal events between New and Old world forests were common in the Paleogene. Our report of LI. sandovalii from Panama, Central America adds to the understanding of the historical biogeography of Anacardiaceae and helps support the theory that Central America (including Mexico) was a divergence center of the family in the past. 


\section{Acknowledgements}

We thank the Ministerio de Comercio e Industrias (MICI) for collection permits and Mr. Carlos Sandoval for allowing us to collect fossils on his private farm. We acknowledge valuable help in the field from Judith Callejas-Moreno, César Silva, Miguel Martínez and the Carlos Jaramillo's lab in the CTPA (Center for Tropical Palaeoecology and Archaeology), Panama. We really appreciate the comments to our manuscript from an anonymous reviewer, Dr. Mariana Brea and Dr. Roberto Pujana. We are grateful to Biól. Diana K. PérezLara from Instituto Politécnico Nacional for her help with the images and to Susana Guzmán at the Instituto de Biología, UNAM, for microphotography assistance. We thank Dori Lynne Contreras (University of California) for comments on an early version of the manuscript. We particularly thank Dra. Teresa Terrazas, an expert on Anacardiaceae wood anatomy for discussions on the identification of the fossils. This research has been funded by the SENACyT ITE15-023 grant to Oris J. Rodríguez-Reyes and SIP-IPN (20195100) and CONACyT (240241) grants to E.E.R.

\section{References}

Agarwal, A. 1988. Occurrence of Bouea in the Neyveli lignite deposits, India: Geophytology, 18(2), 166-168.

Allen, S.E., 2017, Reconstructing the Local Vegetation and Seasonality of the Lower Eocene Blue Rim Site of Southwestern Wyoming Using Fossil Wood: International Journal of Plant Sciences, 178(9), 689-714. https://doi.org/10.1086/694186

Angiosperm Phylogeny Group, IV. 2016, An update of the Angiosperm Phylogeny Group classification for the orders and families of flowering plants: APG IV. Botanical Journal of the Linnean Society, 181(1), 1-20. https:// doi.org/10.1111/boj.12385

Awasthi, N., Srivastava, R., 1990. Some new carbonized woods from the Neogene of Kerala Coast and their bearing on palaeoclimate: Palaeobotanist 38, 285-292.
Bell, G.D., Soltis, D.E., Soltis, P.S., 2010, The age and diversification of the angiosperms revisited: American Journal of Botany 97(8), 1296-303. https://doi.org/10.3732/ ajb.0900346

Biondi, E., 1981. Arganioxylon sardum n. gen., n. sp. Et Sclerocaryoxylon chiarugii n. gen., n. sp. : bois fossiles du Miocène de la Sardaigne (Italie): Review of Palaeobotany and Palynology 34, 301-320. https://doi. org/10.1016/0034-6667(81)90047-6

Buchs, D.M., Arculus, R.J., Baumgartner, P.O., Ulianov, A., 2011, Oceanic intraplate volcanoes exposed: example from seamounts accreted in Panama: Geology, 39(4), 335338. https://doi.org/10.1130/g31703.1

Cheng, Y.-M., Mehrotra, R.G., Jin, Y.-G., Yang, W., Li, C.-S., 2012, A new species of Pistacioxylon (Anacardiaceae) from the Miocene of Yunnan, China: IAWA Journal, 33(2), 197-204. https://doi. org/10.1163/22941932-90000089

Dayal, R.,1965, Occurrence of Boswellia in the Deccan Intertrappean beds of Keria, Madhya Pradesh: Current Science 33(22), 683-84.

Den Berger, L.G. 1923. Fossiele houtsoorten uit het Tertiair van Zuid-Sumatra. Verh. Mijnb. Genoot. Ned. : Geologie enmijnbouw 7, 143-148.

Estrada-Ruiz, E., Martínez-Cabrera, H.I., Cevallos-Ferriz, S.R.S., 2010, Fossil woods from the Olmos Formation (late Campanian-early Maastrichtian), Coahuila, Mexico: American Journal of Botany, 97(7), 1179-1194.

Franco, M.J., 2009, Leños fósiles de Anacardiaceae en la Formación Ituzaingó (Plioceno), Toma Vieja, Paraná, Entre Ríos, Argentina: Ameghiniana, 46(4), 587-604.

Franco, M.J., Brea, M., 2008, Leños fósiles de la Formación Paraná (Mioceno Medio), Toma Vieja, Paraná, Entre Ríos, Argentina: registro de bosques estacionales mixtos: Ameghiniana, 45(4), 699-717.

Gentry, A.H., 1988, Changes in Plant Community Diversity and Floristic Composition 
on Environmental and Geographical Gradients: Annals of the Missouri Botanical Garden, 75(1), 1-34. https://doi. org / 10.2307/2399464

Gregory, M., Poole, I., Wheeler, E.A., 2009, Fossil dicot wood names, an annotated list with full bibliography: IAWA Journal Supp., 6, 220 pp.

Herrera, F., Manchester, S., Jaramillo, C., 2012, Permineralized fruits from the late Eocene of Panama give clues of the composition of forests established early in the uplift of Central America: Review of Palaeobotany and Palynology, 175, 10-24. https://doi. org/10.1016/j.revpalbo.2012.02.007

IAWA Committee., 1989, List of microscopic features for hardwood identification. IAWA Bull. 10(3), 219-329. Available in: https://www.iawa-website.org/uploads/ soft/Abstracts/IAWA $\% 20$ list $\% 20$ of $\% 20$ microscopic $\% 20$ features $\% 20$ for $\% 20$ hardwood $\% 20$ identification.pdf

Jud, N.A., Dunham, J.I., 2017, Fossil woods from the Cenozoic of Panamá (Azuero Peninsula) reveal an ancient neotropical rainforest: IAWA Journal, 38(3), 366-S2. https://doi. org/10.1163/22941932-20170176

Kolarsky, R.A., Mann, P., Monechi, S., Meyerhoff, H.D., Pessagno, Jr. E.A., 1995, Stratigraphic development of southwestern Panama as determined from integration of marine seismic data and onshore geology. In: Mann, P. (Ed.). Geologic and tectonic development of the Caribbean Plate boundary in southern Central America, pp. 159-200.

Kruse, H.O., 1954. Some Eocene dicotyledonous woods from Eden Valley, Wyoming: Ohio Journal of Science 54(4), 243-268.

León, H.W.J., 2003, Estudio anatómico del xilema secundario de 17 especies de la familia Anacardiaceae en Venezuela: Acta Botánica Venezuelica, 26(1), 1-30.

León, H.W.J., 2014, Anatomía de maderas de 108 especies de Venezuela: Revista Pitteria, número especial, 1-267.
Martínez-Cabrera, H.I., Cevallos-Ferriz, S.R.S., 2004, A new species of Tapirira from Early Miocene sediments of the El Cien Formation, Baja California: IAWA Journal, 25 (1), 103-117. https://doi. org/10.1163/22941932-90000353

Martínez-Cabrera, H. I., Cevallos-Ferriz, S. R., \& Poole, I. 2006, Fossil woods from early Miocene sediments of the El Cien Formation, Baja California Sur, Mexico: Review of Palaeobotany and Palynology, 138(34), 141-163. https://doi.org/10.1016/j. revpalbo.2006.01.001

Méndez-Cárdenas. J.P., Cevallos-Ferriz, S.R.S., Calvillo-Canadell, L., Rodríguez-Yama, G.A., Borja, A.M., Martínez-Cabrera, H.I., 2014, Loxopterygium wood in Coayuca de Andrade, Oligocene of Puebla, Mexico: Review of Palaeobotany and Palynology, 207, 38-43.

Niklas, K.J., 1995, Size-dependent allometry of tree height, diameter and trunk taper: Annals of Botany, 75(3), 217-227. https:// doi.org/10.1006/anbo.1995.1015

Pennington, R.T., Lavin, M., Särkinen, T., Lewis, G.P., Klitgaard, B.B., Hughes, G.E., 2010, Contrasting plant diversification histories within the Andean biodiversity hotspot: Proceedings of the National Academy of Sciences, 107(31), 13783-13787. https:// doi.org/10.1073/pnas. 1001317107

Pérez-Lara, D.K., Castañeda-Posadas, C., Estrada-Ruiz, E., 2017, A new genus of Anacardiaceae from El Bosque Formation (Eocene), Chiapas, Mexico: IAWA Journal, 38(4), 543-552. https://doi. org/10.1163/22941932-20170179

Pujana, R.R., 2009, Fossil woods from the Oligocene of southwestern Patagonia (Rio Leona Formation). Atherospermataceae, Myrtaceae, Leguminosae and Anacardiaceae: Ameghiniana, 46(3), 523-535.

Ramírez, J.L., Cevallos-Ferriz, S.R.S., SilvaPineda, A., 2000, Reconstruction of leaves 
of two new species of Pseudosmodingium from Oligocene strata of Puebla, México: International Journal of Plant Sciences, 161(3), 509-519. https://doi. org/10.1086/314261

Roy, S.K., Ghosh P.K. . 1979-80,1981, Fossil woods of Anacardiaceae from the Tertiary of west Bengal, India: The Palaeobotanist 28/29, 338-352. http://14.139.63.228:8080/ pbrep/handle/123456789/1105

Shukla, A., Mehrotra, R.G., 2016, Holigarna (Anacardiaceae) from the early Eocene of Western India and its palaeogeographical and palaeoclimatological significance: Journal of the Geological Society of India, 87(5), 520-524. https://doi.org/10.1007/ s12594-016-0425-6

Stevens, P.F., 2001 onwards, Angiosperm Phylogeny Website, Version 9. Available in: http://www.mobot.org/MOBOT/ research/APweb/

Terrazas, T., 1994, Wood anatomy of the Anacardiaceae: ecological and phylogenetic interpretation: Chapel Hill, N.C., Department of Biology, University of North Carolina, $\mathrm{PhD}$ thesis, $321 \mathrm{p}$.

Terrazas, T., 1999, Anatomía de la madera de Anacardiaceae con énfasis en los géneros americanos: Boletín de la Sociedad Botánica de México, 64, 103-109.

Weeks, A., Zapata, F., Pell, S.K., Daly, D.C.,
Mitchell, J.D., Fine, P.V.A., 2014, To move or to evolve: contrasting patterns of intercontinental connectivity and climatic niche evolution in "Terebinthaceae" (Anacardiaceae and Burseraceae): Frontiers in Genetics 5, 409. http://dx.doi.org/10.3389/ fgene.2014.00409

Wheeler, E.A., 2011, Inside wood - A web resource for hardwood anatomy: IAWA Journal, 32(2), 199-211. https://doi. org/10.1163/22941932-90000051

Wheeler, E.A., Manchester, S.R., 2002, Woods of the Middle Eocene Nut Beds Flora, Clarno Formation, Oregon, USA: IAWA Journal Supplement 3, 188 pp.

Wheeler, E.A., Srivastava, R., Manchester, S.R., Baas, P., 2017, Surprisingly modern latest Cretaceous-earliest Paleocene woods of India: IAWA Journal, 38(4), 456-542. https:// doi.org/10.1163/22941932-20170174

Woodcock, D.W., Meyer, H.W., Prado, Y., 2017, The Piedra Chamana fossil woods (Eocene, Peru): IAWA Journal, 38, 313-365. https:// doi.org/10.1163/22941932-20170175

Xie, L., Yang, Z.Y., Wen, J., Li, D.Z., Yi, T.S., 2014, Biogeographic history of Pistacia (Anacardiaceae), emphasizing the evolution of the Madrean-Tethyan and the eastern Asian-Tethyan disjunctions: Molecular Phylogenetics and Evolution, 77, 136-146. https://doi.org/10.1016/j. ympev.2014.04.006 